\title{
Kualitas Fisik, Mikrobiologis, dan Organoleptik Telur Konsumsi yang Beredar di Sekitar Kampus IPB, Darmaga, Bogor
}

\author{
Physical Quality, Microbiology, and Organoleptic of Egg Around IPB Campus, Dramaga, Bogor
}

\author{
Suharyanto $^{1}$, N. B. Sulaiman ${ }^{2}$, C. K. N. Zebua ${ }^{2}$, I. I. Arief ${ }^{2}$ \\ ${ }^{1}$ Jurusan Peternakan, Fakultas Pertanian Universitas Bengkulu. \\ ${ }^{2}$ Departemen Ilmu Produksi dan Teknologi Peternakan, Fakultas Peternakan IPB. \\ email: suharyanto@unib.ac.id
}

\begin{abstract}
This study was conducted to evaluate physical, microbiological, and organoleptic quality of layer eggs marketed around IPB campus Darmaga, Bogor. Egg samples were obtained from three market groups (supermarket, retailer, and traditional market). Each group includes three markets determined purposively, namely SM-1, SM-2, and SM-3 for supermarkets; BR-1, BR-2, and BR-3 for retailers; and TM-1, TM-2, and TM-3 for traditional markets. Physical qualities measured were egg weight, yolk index, albumen index, air sac height, $\mathrm{pH}$ and Aw. Microbiological quality was expressed as colony forming unit with Total Plate Count (TPC) method and the number of Escherichia coli colony formed. Organoleptic properties evaluated were hedonic and hedonic ranking test. All physical and microbiological qualities of eggs showed no significant differences among markets origin. This study confirmed that eggs excluded from SNI 3926-2008 (Indonesia National Standard for consumption egg) and other scientific findings. However, the low physical and microbiological qualities did not cause any refusing on the acceptability of sensorial properties by panelists.
\end{abstract}

Key words: egg, microbiological, organoleptic, physical

\section{PENDAHULUAN}

Telur merupakan produk peternakan yang cukup populer dan banyak dikonsumsi dibanding produk peternakan lainnya. Berdasarkan data statistik, konsumsi telur ayam ras di Indonesia bertumbuh sebesar 1,61\% dalam rentang waktu tahun 2009-2013 (BPS 2014). Hal ini karena telur ayam ras khususnya merupakan komoditas yang relatif terjangkau dan memiliki gizi yang tinggi sehingga diminati oleh masyarakat.

Namun demikian, telur yang dikonsumsi hendaknya memenuhi kriteria layak konsumsi yang diantaranya mencakup kualitas fisik, mikrobiologi, dan organoleptik. Telur yang sampai ke konsumen akhir biasanya terdistribusi melalui beberapa rantai tataniaga mulai dari produsen, distributor, pedagang pengumpul, dan pedagang pengecer (Suharyanto 2007b). Oleh karenanya telur yang sampai ke konsumen sudah tidak baru lagi. Menurut Suharyanto (2007b) bahwa rata-rata telur yang berada pada pedagang pengecer sudah berumur lebih dari 7 hari.

Distribusi telur dari distributor ke pedagang pengecer telah menunjukkan adanya penurunan kualitas fisik (Suharyanto 2007a). Semakin lama periode penyimpanan telur mengakibatkan berat dan tinggi putih telur lebih rendah sementara $\mathrm{pH}$ putih telur menjadi lebih tinggi (Scott dan Silversides 2000). Hasil penelitian Jones dan Musgrove (2004) juga memperlihatkan bahwa selama penyimpanan, berat telur menurun dari kira-kira 61 gram menjadi 57 gram setelah 10 minggu penyimpanan. Tinggi putih telur juga menurun dari $7,05 \mathrm{~mm}$ menjadi $4,85 \mathrm{~mm}$. Demikian halnya dengan cemaran mikroba telur mengalami peningkatan (Jones et al. 2004).

Berdasarkan hal di atas maka penting untuk mengevaluasi kualitas fisik, mikrobiologis, dan organoleptik atas telur konsumsi di masyarakat dengan studi kasus pada telur yang beredar di sekitar kampus IPB, Darmaga, Bogor.

\section{MATERI DAN METODE}

\section{Sampel Telur}

Penelitian ini menggunakan telur yang diambil secara sampling dari 3 kelompok pasar dimana tiap-tiap kelompok pasar ditentukan tiga lokasi penjualan telur. Ketiga jenis pasar tersebut adalah supermarket (SM-1, SM2, SM-3), pasar eceran (BR-1, BR-2, BR-3), pasar tradisional (TM-1, TM-2, TM-3). Penentuan lokasi dilakukan secara sengaja (purposive) dengan pertimbangan di lokasi tersebut merupakan pusat jual beli telur yang konsumen akhir langsung membelinya.

Tiap lokasi, telur diambil secara acak dan kemudian dibawa ke laboratorium terpadu Ilmu Produksi dan Teknologi Peternakan (IPTP) IPB untuk dianalisa kualitas fisik, mikrobiologis, dan organoleptiknya.

\section{Kualitas Fisik}

Kualitas fisik yang diukur mencakup indeks putih telur, indeks kuning telur, tinggi kantung udara yang 
semuanya diukur dengan menggunakan jangka sorong, $\mathrm{pH}$ dan Aw telur. Nilai Indeks putih dan kuning telur ditentukan dengan membagi tinggi putih atau kuning telur dengan diameter putih atau kuningnya, dan $\mathrm{pH}$ telur dilakukan dengan mencampur bagian putih dan kuning telur sehomogen mungkin kemudian diukur dengan menggunakan pH-meter (Schott Instruments Lab 850). Aw telur dilakuan dengan mencampur bagian putih dan kuning telur hingga homogen kemudian diukur dengan menggunakan Aw-meter (Novasina Ms-1).

\section{Kualitas Mikrobiologis}

Kualitas mikrobiologis ditentukan dengan Total Plate Count (TPC) dan jumlah Escherichia coli. TPC dilakukan dengan mencampur bagian putih dan kuning telur hingga homogen. Sebanyak $25 \mathrm{~mL}$ sampel homogen dimasukkan ke dalam $225 \mathrm{~mL}$ media $\mathrm{NaCl}$ fisiologis dan dihomogenkan sebagai pengenceran $10^{-1}$ (P1). Larutan dari P1 dipindahkan $1 \mathrm{~mL}$ ke dalam larutan $9 \mathrm{~mL} \mathrm{NaCl}$ fisiologis dan merupakan pengenceran $10^{-2}$ (P2). Cara yang sama dilakukan pada setiap seri pengenceran hingga pada pengenceran $10^{-6}(\mathrm{P} 6)$.

Larutan dari pengenceran $10^{-4}(\mathrm{P} 4), 10^{-5}$ (P5), dan $10^{-6}$ (P6) masing-masing dipipet sebanyak $1 \mathrm{~mL}$ dan dimasukkan ke dalam cawan petri steril yang berbeda kemudian dituangkan sebanyak 15-20 mL media PCA (Oxoid CM 0325) steril. Tiap seri pengenceran dibuat duplo. Media dalam cawan yang telah berisi sampel dibiarkan hingga memadat dan diinkubasi dengan posisi terbalik pada temperatur $37{ }^{\circ} \mathrm{C}$ selama 24-48 jam. Setelah 24-48 jam, dilakukan penghitungan koloni dengan menggunakan colony counter berdasarkan ketentuan Standard Plate Count (SPC). Penetapan jumlah koloni dilakukan dengan menggunakan metode Bacteriological Analitical Manual (BAM).

Larutan pengenceran $10^{-1}, 10^{-2}$, dan $10^{-3}$ digunakan untuk menentukan jumlah E. coli. Sebanyak $1 \mathrm{~mL}$ dari tiaptiap pengenceran dimasukkan ke dalam cawan petri yang berbeda. Tiap seri pengenceran dibuat duplo. Kemudian cawan petri tersebut dituang media Eosin Methylene Blue Agar (EMBA, Himedia M022-500G) steril. Setelah media membeku maka diinkubasi dengan posisi terbalik pada temperatur $37{ }^{\circ} \mathrm{C}$ selama 24-48 jam. Setelah 24-48 jam, dilakukan penghitungan koloni E. coli.

\section{Kualitas Organoleptik}

Kualitas organoleptik telur dilakukan dengan melakukan penilaian uji hedonik dan uji mutu hedonik (Meilgaard et al. 1999). Penilaian uji hedonik dan mutu hedonik mencakup atribut penampilan, warna, aroma, warna putih relur, warna kuning telur, tekstur putih telur dan tekstur kuning telur. Skala penilaian uji hedonik untuk semua atribut adalah $1=$ sangat tidak suka, $2=$ tidak suka, 3 $=$ netral, $4=$ suka, 5 = sangat suka. Sedangkan skala skor uji mutu hedonik untuk atribut aroma adalah $1=$ sangat amis, $2=$ lebih amis, $3=$ amis, $4=$ kurang amis, $5=$ sangat tidak amis; rasa adalah $1=$ sangat tidak enak, 2 = tidak enak, 3 = enak, 4 = lebih enak, 5 = sangat enak; warna kuning telur adalah 1 = sangat tidak kuning, 2 = tidak kuning, $3=$ kuning, 4 = lebih kuning, 5 = sangat kuning; warna putih telur adalah 1 = sangat tidak putih, 2 = tidak putih, $3=$ putih, 4 = lebih putih, 5 = sangat putih; dan tekstur kuning dan putih telur adalah $1=$ sangat tidak kenyal, $2=$ tidak kenyal, 3 = kenyal, 4 = lebih kenyal, $5=$ sangat kenyal.

Penilaian kualitas organoleptik dilakukan oleh 14 panelis semi terlatih terhadap sampel telur rebus yang telah diberi kode 3 digit angka acak untuk tiap sampel berdasarkan sub kelompok pasar. Pengujian dilakukan di laboratorium organoleptik IPTP IPB. Setiap sampel ditempatkan pada wadah yang seragam bentuk, warna, dan ukurannya. Setiap panelis disediakan air minum.

\section{Analisa Data}

Data fisik dan mikrobiologi dianalisa dengan anova pola satu arah dan bila terdapat perbedaan nyata antar kelompok pasar pada selang kepercayaan 95\% maka dilakukan uji lanjut dengan menggunakan Duncan's New Multiple Range Test. Data organoleptik diuji dengan menggunakan Kruskal-Wallis pada selang kepercayaan 95\%. Data yang tidak memenuhi kaidah statistik diuraikan secara deskriptif.

\section{HASIL DAN PEMBAHASAN}

\section{Kualitas Fisik}

Hasil pengamatan kualitas fisik telur konsumsi disajikan pada Tabel 1. Semua peubah menunjukkan adanya perbedaan yang tidak nyata antar kelompok pasar. Artinya kondisi fisik telur yang berasal dari supermarket, pedagang eceran, dan pasar tradisional memiliki kualitas yang sama.

Telur dari semua kelompok pasar termasuk dalam kategori besar. Kategori bobot telur berdasarkan Badan Standardisasi Nasional adalah telur kecil $(<50$ gr), sedang (50-60 gr), dan besar (>60 gr) (BSN 2008). Namun bila dilihat berdasarkan indikator Indeks Kuning Telur (IKT), Indeks Putih Telur (IPT), dan Tinggi Kantung Udara (TKU) maka telur dari semua kelompok pasar telah tidak memenuhi syarat SNI 2008 sebagai telur konsumsi. Hal ini menunjukkan bahwa telur sampel telah berumur simpan yang lama. Menurut SNI 3926-2008 bahwa persyaratan mutu fisik telur konsumsi tertera pada Tabel 2 (BSN 2008).

Tabel 1 Rataan kondisi fisik sampel telur ayam ras dari berbagai kelompok pasar

\begin{tabular}{lllllll}
\hline Asal Telur (Sampel) & BT & IKT & IPT & \multirow{2}{*}{ TKU (mm) } & Aw & \multirow{2}{*}{ pH } \\
\cline { 2 - 4 } & $(\mathrm{g})$ & $(\mathrm{mm})$ & $(\mathrm{mm})$ & & & \\
\hline Supermarket (SM-1, SM-2, SM-3) & $63,43+5,76$ & $0,24+0,06$ & $0,04+0,02$ & $8,57+5,53$ & $0,87+0,00$ & $7,98+0,54$ \\
Eceran (BR-1, BR-2, BR-3) & $61,70+4,54$ & $0,25+0,05$ & $0,04+0,02$ & $4,11+1,36$ & $0,86+0,01$ & $8,51+0,15$ \\
Pasar Tradisional (TM-1, TM-2, TM-3) & $66,53+1,46$ & $0,25+0,04$ & $0,05+0,01$ & $10,18+0,88$ & $0,86+0,01$ & $8,56+0,32$ \\
\hline
\end{tabular}

Keterangan: Tidak ada perbedaan nyata antar kelompok pasar pada semua peubah $(\mathrm{P}>0,05), \mathrm{BT}=$ Berat telur, IKT=Indeks Kuning Telur, IPT=Indeks Putih telur, TKU=Tinggi Kantung Udara, TK=Tebal Kerabang. 
Tabel 2 Syarat mutu telur konsumsi menurut SNI 3926-2008

\begin{tabular}{lccc}
\hline Kondisi Fisik & Mutu I & Mutu II & Mutu III \\
\hline Kantong Udara & $<0,5 \mathrm{~cm}$ & $0,5-0,9 \mathrm{~cm}$ & $>0,9 \mathrm{~cm}$ \\
Indeks Putih Telur & $0,134-0,175$ & $0,092-0,133$ & $0,05-0,091$ \\
Indeks Kuning telur & $0,458-0,521$ & $0,394-0,457$ & $0,330-0,339$ \\
\hline
\end{tabular}

Sumber: BSN, 2008

Meskipun masih masuk kategori besar, diduga berat telur telah mengalami penurunan seiring dengan umur simpan. Berat telur menurun sebesar 1,87\% bila disimpan selama 10 hari dan menurun sebesar 3,09\% bila disimpan selama 15 hari (Nova et al. 2014). Penyimpanan 1 minggu menurunkan berat telur sebesar $1,59 \%$ dan 2 minggu menurun sebesar 3,6\% (Jazil et al. 2013). Penurunan berat terjadi karena adanya penguapan dan hilangnya gas $\mathrm{CO}_{2}$, $\mathrm{NH}_{3}, \mathrm{~N}_{2}, \mathrm{H}_{2} \mathrm{~S}$, dan air dari albumen (Buckle et al. 1987).

Dugaan bahwa semua telur sampel telah berumur simpan lama dikuatkan dengan adanya nilai IKT, ITP, dan TKU beberapa penelitian yang lain. Sejalan dengan penyimpanan, nilai indeks tersebut mengalami penurunan (Suharyanto 2007b). Bertambahnya umur penyimpanan menyebabkan tinggi kuning telur menurun sehingga nilai indeksnya rendah (Scott dan Silversides 2000). Penyimpanan selama 7 hari, telur mempunyai IKT 0,3690,371, penyimpanan 14 hari menyebabkan IKT menjadi 0,275-0,290. Sedangkan IPT pada penyimpanan 7 hari adalah 0,045-0,048 dan penyimpanan 14 hari adalah 0,0340,041 (Jazil et al. 2013). Penyimpanan 7 hari meningkatkan TKU menjadi 5,69 mm, penyimpanan 14 hari menjadi 8,52 mm dari 2,19 $\mathrm{mm}$ pada hari pertama (Jazil et al. 2013). Hasil penelitian ini memperlihatkan nilai IKT dan IPT masing-masing berkisar antara 0,24-0,25; 0,4-0,5; dan TKU 4,11-10,18 mm (Tabel 1).

Selama masa simpan terjadi proses perpindahan air dari putih telur ke kuning telur disertai dengan peregangan dan pecahnya membran vitelina. Hal ini menyebabkan pelebaran kuning telur sehingga menurunkan nilai IKT. Pada saat bersamaan terjadi penguapan air dari putih telur sehingga terjadi pelebaran posisi putih telur dan menyebabkan penurunan nilai indeks (Hiroko et al. 2014).

Penyimpanan telah meningkatkan $\mathrm{pH}$ telur (kuning dan putih telur). Penyimpanan selama 1-5 hari tidak menunjukkan peningkatan nyata, tetapi penyimpanan setelah 10 hari menunjukkan kenaikan $\mathrm{pH}$ yang nyata. Telur yang disimpan selama 5, 10, dan 15 hari memiliki $\mathrm{pH}$ masingmasing adalah 6,94; 7,43; dan 7,51 (Nova et al. 2014). Menurut Hiroko et al. (2014), penyimpanan telur selama 7 hari memiliki $\mathrm{pH}$ antara 7,33-7,40 dan penyimpanan selama 14 hari menyebabkan $\mathrm{pH}$ meningkat menjadi 7,307-7,547. Hasil pengamatan ini mengonfirmasi bahwa semua telur sampel berumur simpan sekitar 2 minggu atau lebih. Hal ini terlihat dari kisaran $\mathrm{pH}$ telur, yaitu antara 7,98-8,56 (Tabel 1).

Peningkatan $\mathrm{pH}$ telur diakibatkan oleh adanya penguapan $\mathrm{CO}_{2}$ sehingga merubah keseimbangan $\mathrm{CO}_{2}$, ion bikarbonat, dan protein. $\mathrm{CO}_{2}$ yang hilang mengakibatkan konsentrasi ion bikarbonat menurun dan merusak sistem buffer dan akhirnya $\mathrm{pH}$ putih dan kuning telur menjadi meningkat (Hiroko et al. 2014).

Kisaran nilai Aw telur pada hasil pengamatan ini adalah 0,86-0,87 (Tabel 1) dan tidak berbeda nyata antar asal telur $(\mathrm{P}>0,05)$. Kisaran nilai Aw tersebut memungkinkan untuk tumbuhnya bakteri patogen. Oleh karenanya hasil pengamatan menunjukkan bahwa cemaran mikrobanya cukup tinggi (Tabel 3). Jay (2000) menyatakan bahwa Aw berhubungan dengan nilai biologis dan ketersediaan air pada suatu makanan. Air yang tersedia tersebut pada akhirnya bisa dimanfaatkan bakteri untuk aktivitasnya. Bakteri patogen memanfaatkan air dalam makanan untuk mentransportasikan nutrisi dan juga berperan dalam proses enzimatis.

\section{Kualitas Mikrobiologi}

Hasil pengamatan pada sampel telur yang berasal dari ketiga kelompok pasar menunjukkan tingginya tingkat cemaran mikroba bila dibandingkan dengan SNI. Menurut BSN (2008) bahwa persyaratan mikrobiologi telur konsumsi tidak boleh ada cemaran mikroba lebih dari $1 \times 10^{5}$ atau 5 log. Data hasil pengamatan menunjukkan semua sampel mengandung cemaran mikroba lebih dari 5 log (Tabel 3).

Hasil analisis statistik menunjukkan bahwa jumlah

Tabel 3 Rataan jumlah koloni mikroba (log CFU $\mathrm{mL}^{-1}$ ) sampel telur ayam ras dari berbagai kelompok pasar

\begin{tabular}{|c|c|c|}
\hline Asal Telur (Sampel) & $\begin{array}{c}\log \mathrm{CFU} \mathrm{mL}^{-1} \\
\text { (jumlah koloni } \mathrm{mL}^{-1} \text { ) }\end{array}$ & E. coli \\
\hline $\begin{array}{l}\text { Supermarket (SM-1, SM-2, } \\
\text { SM-3) }\end{array}$ & $\begin{array}{l}6,9+0,417 \\
(1,2 \times 107)\end{array}$ & + \\
\hline Eceran (BR-1, BR-2, BR-3) & $\begin{array}{l}6,6+0,162 \\
(2,0 \times 106)\end{array}$ & - \\
\hline $\begin{array}{l}\text { Pasar Tradisional (TM-1, } \\
\text { TM-2, TM-3) }\end{array}$ & $\begin{array}{l}6,3+0,185 \\
(4,1 \times 106)\end{array}$ & + \\
\hline
\end{tabular}

Keterangan: tidak terdapat perbedaan nyata $\log \mathrm{CFU} \mathrm{mL} \mathrm{m}^{-1}$ antar kelompok pasar $(\mathrm{P}>0,05)$. Data jumlah koloni ditransformasi ke dalam bentuk log

cemaran mikroba dari semua kelompok pasar tidak berbeda nyata $(\mathrm{P}>0,05)$. Namun demikian, cemaran tertinggi justru didapati pada sampel telur dari supermarket. Tidak adanya perbedaan cemaran mikroba antar kelompok pasar menunjukkan kemungkinan umur telur yang berada di semua kelompok pasar memiliki umur simpan yang relatif sama. Hal ini ditunjukkan juga dengan semua sampel memperlihatkan jumlah cemaran yang sama-sama melebihi batas maksimum yang diizinkan dalam SNI, yaitu $10^{5} \mathrm{CFU}$ $\mathrm{g}^{-1}$ atau $5 \mathrm{log}$. Namun demikian, hanya dijumpai 3 sampel yang mengandung cemaran $E$. coli sebanyak 1 koloni pada 2 supermarket dan 1 pasar tradisional.

Tingginya cemaran mikroba diduga karena umur simpan telur yang telah lama karena melalui beberapa rantai tataniaga. Biasanya telur sampai ke konsumen terakhir telah melewati beberapa jalur distribusi yaitu produsen, distributor, pedagang pengumpul, dan pedagang eceran (Suharyanto 2007a). Panjangnya jalur tataniaga menyebabkan lamanya waktu telur disimpan pada kondisi suhu ruang. Hal ini menyebabkan cemaran mikroba telur 
terus berkembang (Lubis et al. 2012; Finata et al. 2015). Menurut Idayanti et al. (2009) bahwa telur yang disimpan pada suhu $29^{\circ} \mathrm{C}$ selama 6 hari tercemar mikroba sebanyak $1,2 \times 10^{6}$ dan selama 12 hari cemarannya mencapai $8,3 \times$ $10^{6}$ serta penyimpanan selama 18 hari mencapai $2,1 \times 10^{7}$ CFU $\mathrm{mL}^{-1}$.

Cemaran E. coli penelitian ini jauh lebih rendah dari hasil penelitian Lubis et al. (2012) dan (Finata et al. 2015) yang menunjukkan banyaknya cemaran E. coli pada telur ayam kampung dan telur itik pada penyimpanan suhu kamar. Hal ini diduga karena telur ayam ras dan telur ayam kampung maupun itik berasal dari manajemen yang berbeda. Ayam ras petelur dipelihara secara intensif sehingga tingkat cemarannya lebih rendah dibanding telur yang berasal dari pemeliharaan ekstensif seperti pada ayam kampung dan itik. Menurut De Reu et al. (2006) manajemen perkandang mempengaruhi jumlah kontaminasi bakteri pada telur. Namun karena diduga umur telur telah lama dan disimpan pada suhu ruang maka tingkat cemaran total bakteri telah melampaui batas maksimum yang diizinkan.

Pada umumnya sumber cemaran bakteri pada telur adalah berasal dari saluran reproduksi, berupa bakteri enterobacter, E. coli, Proteus, dan Salmonella dengan tingkat laju penetrasi berbeda-beda antar jenis dan strain bakteri (Al-Bahry et al. 2012). Cemaran umumnya berasal dari peternakan dan selama kondisi penyimpanan. Hal ini juga dijumpai pada adanya cemaran pada pasar dan peternakan (Chaemsanit et al. 2015).

\section{Kualitas Organoleptik}

Kualitas organoleptik telur sampel terlihat dari median (nilai tengah) tanggapan panelis terhadap sampel telur yang diuji sebagaimana disajikan pada Tabel 4 dan 5 . Tabel 4 adalah median tanggapan panelis terhadap penilaian hedonik telur setelah uji Kruskal-Wallis.

Nilai P pada median penampilan telur menunjukkan adanya perbedaan kesukaan panelis $(\mathrm{P}<0,05)$. Telur yang berasal dari SM-2, pasar eceran BR-2, TM-1, dan TM-2 disukai oleh panelis (skor 4). Sedangkan telur dari BR-1 tidak disukai oleh panelis (skor 2). Panelis menilai netral terhadap telur dari pasar yang lainnya (skor 3). Faktor yang mempengaruhi penampilan mencakup warna dan tekstur dan bersifat kompleks.

Skor yang hampir selaras dengan penampilan telur adalah WKT. Terlihat pada Tabel 4 bahwa skor WKT memiliki pola yang mirip dengan penampilan dan nilai $\mathrm{P}$ median menunjukkan adanya perbedaan nyata $(\mathrm{P}<0,05)$. Panelis menilai tidak suka (skor 2) pada telur BR-3. Telur dari TM-1 dan TM-2 termasuk yang disukai oleh panelis (skor 4) dan panelis menilai netral (skor 3) terhadap telur dari pasar lainnya. Adanya keselarasan nilai skor antara penampilan dan WKT menunjukkan faktor warna kuning telur mempengaruhi panelis terhadap penilaian penampilan telur.

Atribut aroma, WPT, TKT, dan TPT masingmasingnya menunjukkan tidak adanya perbedaan tanggapan panelis $(\mathrm{P}>0,05)$. Secara umum panelis menilai ke-4 atribut tersebut dengan skor 3-4, dari netral hingga menyukai. Kisaran skor pada atribut-atribut tersebut mengisyaratkan bahwa menurunnya kualitas fisik dan organoleptik telur belum mempengaruhi tingkat kesukaan panelis terhadap telur. Secara umum panelis masih menilai bahwa telur masih bisa diterima.

Secara umum panelis menilai hampir sama terhadap mutu hedonik atribut aroma, rasa, WPT, TKT, dan TPT telur $(\mathrm{P}>0,05)$. Skor penilaian yang diberikan panelis antara 2,5-3,5. Ini menunjukkan bahwa panelis cenderung menilai amis pada aroma, enak pada rasa, putih pada WPT, kenyal pada TKT dan TPT. Berbeda dengan atribut WKT, panelis menilai secara berbeda $(\mathrm{P}<0,05)$ sebagaimana terlihat pada Tabel 5. Panelis menilai skor 2,5 (antara tidak kuning dan kuning) pada telur BR-3. Hal ini selaras dengan penilaian hedonik yang mana panelis menilai tidak suka pada WKT BR-3. Warna kuning telur merupakan salah satu faktor penting dalam penilaian sensori telur. Sedangkan skor lain pada WKT cenderung menunjukkan warna kuning dan lebih kuning.

\section{KESIMPULAN}

Telur konsumsi dari ayam ras yang beredar di supermarket, pedagang eceran, dan pasar tradisional sekitar IPB Darmaga, Bogor telah mengalami penurunan kualitas fisik dan mikrobiologis, tetapi konsumen masih aman

Tabel 4 Median tanggapan panelis terhadap penilaian uji hedonik telur

\begin{tabular}{|c|c|c|c|c|c|c|}
\hline Asal Pasar & Penampilan & Aroma & WKT & WPT & TKT & TPT \\
\hline SM-1 & 3 & 3,5 & 3 & 3 & 3 & 4 \\
\hline SM-2 & 4 & 3 & 3 & 4 & 3 & 4 \\
\hline SM-3 & 3 & 3 & 3,5 & 3 & 3 & 3,5 \\
\hline BR-1 & 2 & 3 & 3 & 3 & 3 & 3 \\
\hline BR-2 & 4 & 3 & 3 & 3,5 & 3 & 3 \\
\hline BR-3 & 3 & 3 & 2 & 3 & 3 & 3 \\
\hline TM-1 & 4 & 3 & 4 & 3 & 3 & 3,5 \\
\hline TM-2 & 4 & 3 & 4 & 4 & 3 & 4 \\
\hline TM-3 & 3 & 3 & 3 & 3 & 3 & 3 \\
\hline Nilai P & 0,005 & 0,751 & 0,002 & 0,291 & 0,354 & 0,627 \\
\hline
\end{tabular}

Keterangan: Nilai $\mathrm{P}<0,05$ menunjukkan adanya perbedaan nyata antar asal telur. WKT $=$ Warna Kuning Telur, WPT $=$ Warna Putih Telur, TKT $=$ Tekstur Kuning Telur, TPT Tekstur Putih Telur. 
Tabel 5 Median tanggapan panelis terhadap penilaian uji mutu hedonik telur

\begin{tabular}{|c|c|c|c|c|c|c|}
\hline Asal Pasar & Aroma & Rasa & WKT & WPT & TKT & TPT \\
\hline SM-1 & 3,5 & 3 & 3 & 3 & 3 & 3 \\
\hline SM-2 & 3 & 3 & 4 & 3 & 3 & 3 \\
\hline SM-3 & 2,5 & 3 & 3 & 3 & 2,5 & 3 \\
\hline BR-1 & 4 & 3 & 3 & 3 & 2 & 3 \\
\hline BR-2 & 4 & 3 & 3 & 3 & 3 & 3 \\
\hline BR-3 & 3 & 3 & 2,5 & 3 & 3 & 3 \\
\hline TM-1 & 3 & 3 & 4 & 3 & 3 & 3 \\
\hline TM-2 & 3,5 & 3 & 4 & 3 & 3 & 3 \\
\hline TM-3 & 3,5 & 3 & 3 & 3 & 3 & 3 \\
\hline Nilai P & 0,621 & 0,996 & 0 & 0,626 & 0,867 & 0,819 \\
\hline
\end{tabular}

Keterangan: Nilai $\mathrm{P}<0,05$ menunjukkan adanya perbedaan nyata antar asal telur. WKT $=$ Warna Kuning Telur, WPT $=$ Warna Putih Telur, $\quad$ TKT $=$ Tekstur Kuning Telur, TPT Tekstur Putih Telur.

mengonsumsi telur yang dimasak dengan benar dan matang. Hal ini selaras dengan hasil penilaian organoleptik dimana panelis masih dapat menerima telur konsumsi.

\section{Saran}

Mengonsumsi telur yang berasal dari pasar sekitar kampus IPB Darmaga, Bogor harus melalui proses pemasakan yang benar dan matang serta tidak disarankan mengonsumsi telur setengah matang.

\section{Daftar Pustaka}

[BPS] Badan Pusat Statistik. 2014. Survei Sosial Ekonomi Nasional (Susenas) 2009-2013. Jakarta. Badan Pusat Statistik.

[BSN] Badan Standardisasi Nasional. 2008. Telur Ayam Konsumsi (SNI 3926:2008). Jakarta. Badan Standardisasi Nasional.

Al-Bahry, S., I. Mahmoud, S. Al-Musharafi, M. Al-Ali. 2012. Penetration of spoilage and food poisoning bacteria into fresh chicken egg: a public health concern. Global Journal of Bio-Science and Biotechnology 1(1):33-39.

Buckle, K.A., R. A. Edwards, G. H. Fleet, M. Wootton. 1987. Ilmu Pangan. Jakarta [UI Press.

Chaemsanit, S., A. Akbar, A. K. Anal. 2015. Isolation of total aerobic and pathogenic bacteria from table eggs and its contents. Food and Applied Bioscience Journal 3(1):1-9.

De Reu, K., K. Grijspeerdt, M. Heyndrickx, M. Uyttendaele, J. Debevere, L. Herman. 2006. Bacterial shell contamination in the egg collection chains of different housing systems for laying hens. Br. Poult. Sci. 47(2):163-72. doi:10.1080/00071660600610773

Finata, R.P., M. D. Rudyanto, I.G.K. Suarjana. 2015. Pengaruh lama penyimpanan pada suhu kamar telur itik segar dan telur yang mengalami pengasinan berasal dari UKM Mulyo Mojokerto ditinjau dari jumlah Eschericia coli. Buletin Veteriner Udayana 7(1):41-47.

Hiroko, S.P., T. Kurtini, Riyanti. 2014. Pengaruh lama simpan dan warna kerabang telur ayam ras terhadap indeks albumen, indeks yolk, dan $\mathrm{pH}$ telur. Jurnal
Ilmiah Peternakan Terpadu 2(3):108-114.

Idayanti, S. Darmawati, U. Nurullita. 2009. Perbedaan variasi lama simpan telur ayam pada peyimpanan suhu almari es dengan suhu kamar terhadap total mikroba. Jurnal Kesehatan 2(1):19-26.

Jay, J.M. 2000. Modern Food Microbiology. Gaithersburg (DE) [Aspen Publisher Inc.

Jazil, N., A. Hintono, S. Mulyani. 2013. Penurunan kualitas telur ayam ras dengan intensitas warna coklat kerabang berbeda selama penyimpanan Jurnal Aplikasi Teknologi Pangan 2(1):43-47.

Jones, D., M. Musgrove. Effects of extended storage on egg quality factors. [Internet]. Poult Sci; 2004: POULTRY SCIENCE ASSOC INC $1111 \mathrm{~N}$ DUNLAP AVE, SAVOY, IL 61874-9604 USA. hlm 11-12.

Jones, D.R., M. T. Musgrove, J. K. Northcutt. 2004. Variations in external and internal microbial populations in shell eggs during extended storage. $J$ Food Prot 67(12):2657-2660.

Lubis, H.A., I. G. K. Suarjana, M. D. Rudyanto. 2012. Pengaruh suhu dan lama penyimpanan telur ayam kampung terhadap jumlah Escherichia coli. Indonesia Medicus Veterinus 1(1):144-159.

Meilgaard, M., G. V. Civile, B. T. Carr. 1999. Sensory Evaluation Techniques. Washington DC (US) [CRC Press.

Nova, I., T. Kurtini, V. Wanniatie. 2014. Pengaruh lama penyimpanan terhadap kualitas internal telur ayam ras pada fase produksi pertama. Jurnal Ilmiah Peternakan Terpadu 2(2):16-21.

Scott, T., F. Silversides. 2000. The effect of storage and strain of hen on egg quality. Poult Sci 79(12):17251729.

Suharyanto. 2007a. Kualitas telur ayam ras yang beredar di Kota Bengkulu. Agriculture 8(1): 11-17.

Suharyanto. 2007b. Umur dan berat telur ayam ras yang beredar di Kota Bengkulu. Jurnal Sain Peternakan Indonesia 2(1):22-26. 